\title{
Strategi Pemasaran DOC Ayam Ras Pedaging pada CV Missouri, Bandung Jawa Barat
}

\author{
Marketing Strategy of DOC Broiler at CV Missouri, Bandung West Java
}

\author{
Jamarizal $^{1}$, Suryahadi ${ }^{2}$, dan Rizal Syarief ${ }^{3}$ \\ ${ }^{1}$ Kementerian Pertanian Republik Indonesia \\ Jl. Harsono RM No 3, Ragunan, Jakarta 12550 \\ ${ }^{2}$ Departemen Ilmu Nutrisi dan Teknologi Pakan, Fakultas Peternakan, Institut Pertanian Bogor \\ Jl. Agatis, Kampus IPB Darmaga Bogor 16680 \\ ${ }^{3}$ Departemen Ilmu dan Teknologi Pangan, Fakultas Teknologi Pertanian, Institut Pertanian Bogor \\ Jl. Kamper Kampus IPB Darmaga Bogor 16680
}

\begin{abstract}
ABSTRAK
Usaha peternakan ayam ras pedaging tidak terlepas dari beberapa kendala yang dihadapi. Kendala yang dimaksud adalah tingginya tingkat resiko yang dihadapi dalam usaha ternak ayam ras seperti risiko fluktuasi harga, baik harga-harga input seperti day old chick (DOC), pakan dan obat-obatan maupun fluktuasi harga jual output berupa ayam hidup (livebird) dan karkas. Risiko lain yang dihadapi adalah risiko produksi yang disebabkan oleh cuaca, iklim, penyakit dan risiko sosial. Tujuan dari penelitian ini adalah (1) mendeskripsikan faktor-faktor yang dihadapi oleh CV Missouri dalam pemasaran DOC ayam ras pedaging, (2) menguraikan strategi yang ditempuh oleh CV Missouri untuk mengatasi faktor-faktor dalam pemasaran DOC ayam ras pedaging, dan (3) menentukan bentuk alternatif strategi pemasaran yang dikembangkan oleh CV Missouri dalam memasarkan DOC ayam ras pedaging. Posisi strategis CV Missouri berdasarkan analisis Matrik IE berada pada kuadran V, yaitu strategi pertumbuhan dan stabilitas (growth and stability). Hal ini menunjukkan bahwa perusahaan memiliki strategi pertumbuhan dan stabilitas yang baik. Selanjutnya, strategi pemasaran DOC CV Missouri berdasarkan analisis SWOT adalah (a) memperluas jaringan pemasaran dengan optimal. b) menciptakan DOC yang lebih baik dengan meningkatkan produktivitas, (c) menambah permodalan perusahaan agar dapat bersaing dengan pesaing, karena itu dibutuhkan tambahan modal untuk memperlebar peluang pasar. Strategi alternatif yang bisa diterapkan oleh CV Missouri berdasarkan hasil analisis Matrik QSP, yaitu (1) mempertahankan dan menjaga mutu produk yang dihasilkan, dan (2) meningkatkan pelayanan dan loyalitas konsumen.
\end{abstract}

Kata kunci : ayam ras pedaging, DOC, strategi pemasaran

\section{ABSTRACT}

Broiler farming business is inseparable from several obstacles encountered. The obstacles are the high risk faced by broiler breeding business such as the risk of price fluctuation, both input prices such as DOC, feedmill and medicines as well as selling price of livebird and carcass fluctuation. Another risk faced by broiler farming is the production risk caused by weather, climate, diseases and social risks. The purpose of this research was (1) to describe factors faced by CV Missouri in marketing broiler DOC, (2) to describe the strategy run by CV Missouri in coping with factors in the marketing of broiler DOC, and (3) to determine the alternative form of marketing strategy developed by CV Missouri in marketing broiler DOC. CV Missouri's strategic position based on IE matrix is in quadrant V. It means that the company has a good growth strategy and stability. Moreover, marketing strategies of DOC in CV Missouri based on SWOT analysis are (a) expanding network marketing optimally; b) creating a better DOC by

\footnotetext{
$\left.{ }^{*}\right)$ Korespondensi:

Jl. Harsono RM No 3 Ragunan, Jakarta 12550; email: jama_rizal@yahoo.com
} 
increasing productivity; and (c) increasing the company's capital to compete with competitors, therefore additional capital is required to make market opportunities wider. Alternative strategies which could be implemented by CV Missouri based on QSP matrix analisys are (1) keeping and maintaining the quality of products produced, (2) improving services and consumers loyalties.

Key words: broiler, DOC, marketing strategy

\section{PENDAHULUAN}

Salah satu tujuan dalam pembangunan sektor pertanian adalah terpenuhi kebutuhan pangan penduduk yang terus meningkat. Swasembada pangan harus dimantapkan dalam arti luas tidak hanya terbatas pada beras akan tetapi mencakup kebutuhan pangan rakyat secara total, termasuk hasil ternak yang merupakan sumber karbohidrat, protein dan lemak. Kondisi ini akan mendorong terciptanya sistem pangan yang berkelanjutan (Priyadi et al., 2004).

Masalah pangan dalam hal pemenuhan gizi sampai saat ini masih menjadi suatu problem yang belum sepenuhnya dapat terpecahkan apalagi di daerah pedesaan, hal ini akan terlihat jelas karena kondisi ekonominya yang masih rendah. Untuk mengatasi masalah tersebut maka usaha peternakan ayam broiler merupakan salah satu alternatif pemecahan masalah mengatasi kekurangan gizi, terutama kekurangan protein hewani. Hal ini didukung karena ayam broiler pertumbuhannya relatif cepat sehingga cepat pula dapat diambil hasilnya, dan pada akhirnya nanti kebutuhan protein hewani dapat dipenuhi (Jaelani et al., 2013).

Salah satu komoditas strategis dalam pemenuhan kebutuhan protein hewani yang membutuhkan pemilihan bibit unggul adalah pada bidang perunggasan (Siregar et al., 2005). Secara keseluruhan komoditas unggas mengalami peningkatan dari tahun ke tahun. Sejak tahun 1980, industri ayam ras berkembang dengan pesat guna memenuhi kebutuhan dalam negeri dengan arah pembangunan industri ayam ras cenderung menuju usaha padat modal sekalipun pemerintah pada periode 1975-1995 telah melakukan intervensi baik pada aspek teknologi, pembatasan skala usaha dan pemasaran.

Usaha ayam pedaging (broiler) merupakan salah satu jenis usaha yang sangat potensial dikembangkan. Beberapa faktor pendukung usaha budidaya ayam pedaging sebenarnya masih dapat terus dikembangkan, antara lain karena permintaan domestik terhadap ayam pedaging masih sangat besar. Hal ini agar peter- nak atau produsen tidak mengalami kerugian besar dalam usahanya. Jika tidak, maka usaha peternakan yang memiliki manajemen dan strategi yang baik saja yang mampu bertahan dan mampu berkembang. Untuk dapat bertahan atau berkembang, suatu usaha peternakan membutuhkan suatu strategi-strategi tertentu (Ekapriyatna, 2016).

Usaha peternakan ayam broiler tidak terlepas dari beberapa kendala yang dihadapi. Kendala tersebut merupakan hambatan yang cukup kompleks dalam mengusahakan peternakan ayam broiler. Kendala yang dimaksud adalah tingginya tingkat risiko yang dihadapi dalam usaha ternak ayam broiler seperti risiko fluktuasi harga, baik harga-harga input seperti Day Old Chick (DOC), pakan dan obat-obatan maupun fluktuasi harga jual atau output berupa ayam hidup dan daging. Risiko lain yang dihadapi dalam usaha ternak ayam broiler adalah risiko produksi yang disebabkan oleh cuaca dan iklim serta penyakit dan risiko sosial. Hal itulah yang sering menjadi kendala utama dalam bisnis ayam broiler (Yemima, 2014).

Mubyarto (1989) menyatakan bahwa sistem pemasaran dalam bidang pertanian dikatakan efisien jika memenuhi beberapa syarat: (1) mampu menyampaikan hasil pertanian dari produsen ke konsumen dengan biaya semurah-murahnya; dan (2) mampu mengadakan pembagian yang adil dari keseluruhan harga yang dibayar konsumen terakhir kepada semua pihak yang ikut serta didalam kegiatan produksi dan pemasaran barang itu. Adanya efisiensi yang tinggi dalam proses pemasaran maka diharapkan tingkat keuntungan yang diperoleh semakin besar (Tulle et al., 2016). Hal ini sejalan dengan pendapat Soekartawi (1995) bahwa biaya pemasaran yang semakin rendah menyebabkan tingkat keuntungan yang diperoleh akan semakin tinggi dan ini berarti bahwa sistem pemasaran tersebut semakin efisien.

Tujuan dari penelitian ini adalah (1) mendeskripsikan faktor-faktor yang dihadapi oleh CV Missouri dalam pemasaran DOC ayam ras pedaging, (2) menguraikan strategi yang ditempuh oleh CV Missouri untuk mengatasi faktor- 
faktor dalam pemasaran DOC ayam ras pedaging, dan (3) menentukan bentuk alternatif strategi pemasaran yang dikembangkan oleh CV Missouri dalam memasarkan DOC ayam ras pedaging.

\section{METODE PENELITIAN}

Penelitian dilakukan di CV Missouri beralamat di Jalan Malabar No. 53 Bandung dan Breeding Farm di Kabupaten Sumedang, Jawa Barat. Penelitian dimulai dari bulan Februari-Juni 2017.

\section{Pengolahan dan Analisis Data}

\section{Matriks EFE dan IFE}

Matriks External Factor Evaluation (EFE) membantu pengambilan keputusan untuk meringkas dan mengevaluasi informasi lingkungan eksternal, yaitu ekonomi, sosial, budaya, demografi, lingkungan, politik, pemerintah, teknologi, dan sebagainya. Matriks Internal Factor Evaluation (IFE) digunakan untuk meringkas dan mengevaluasi kekuatan dan kelemahan utama yang dihadapi perusahaan.

\section{Matriks IE}

Matriks Internal-External (IE) digunakan untuk melakukan pemetaan terhadap skor total matriks IFE dan EFE yang dihasilkan dari audit eksternal dan internal perusahaan. Matriks IE terdiri atas dua dimensi, yaitu total skor dari matriks IFE dan total skor matriks EFE. Total skor matriks IFE dipetakan pada sumbu $\mathrm{X}$ dengan skor 1,0-1,99 yang menyatakan posisi internal adalah lemah, skor 2,0-2,99 posisinya rataan, serta skor $3,0-4,0$ adalah posisi kuat.

\section{Analisis SWOT}

Menurut Rangkuti (2008), hampir setiap perusahaan maupun pengamat bisnis dalam pendekatannya banyak menggunakan analisis SWOT. Analisis ini mengidentifikasi berbagai faktor secara sistematik untuk merumuskan strategi perusahaan. Analisis ini didasarkan pada logika untuk memaksimalkan kekuatan (strengths) dan peluang (opportunities), namun secara bersamaan dapat meminimalkan kelemahan (weaknesses) dan ancaman (threats).

\section{Matriks QSPM}

Dalam menyusun QSPM (Quantitative Strategic Planning Matrix) perlu dilakukan langkah-langkah berikut (Rangkuti, 2008): a. Membuat daftar kekuatan, kelemahan, peluang dan ancaman usaha di kolom sebelah kiri.

b. Membuat bobot pada masing-masing kekuatan, kelemahan, peluang dan ancaman dengan ketentuan bahwa bobot ini sama dengan bobot pada matriks IFE dan EFE.

c. Menuliskan dan mengidentifikasikan strategi alternatif yang harus dipertimbangkan usaha, yang selanjutnya mencatat strategi-strategi tersebut atas baris QSPM.

d. Menetapkan AS (Attractiveness Score), yaitu nilai yang menunjukkan daya tarik relatif untuk masing-masing strategi yang terpilih. Batasan nilai AS adalah antara 1 sampai 4 . Nilai 1 = tidak menarik, 2 = agak menarik, 3 = secara logis menarik, $4=$ sangat menarik.

e. Menghitung TAS (Total Attractiveness Score) dari hasil perkalian bobot yang terdapat pada matrik IFE dan EFE dengan AS yang diperoleh. TAS menunjukkan daya tarik relatif dari masing-masing alternatif strategi.

f. Menjumlah semua TAS pada masing-masing kolom QSPM. Berdasarkan nilai TAS yang didapat, nilai TAS dari alternatif strategi yang tertinggi menunjukkan bahwa alternatif strategi itu yang menjadi pilihan utama. Nilai TAS terkecil menunjukkan bahwa alternatif strategi ini menjadi pilihan terakhir.

\section{HASIL DAN PEMBAHASAN}

Berawal dari hobi memelihara unggas, Bapak Latif Kartadihardja memulai dan mengembangkan usahanya dibidang peternakan ayam ras di Pangalengan, Kabupaten Bandung (Bandung Selatan), Jawa Barat. Pada tahun 1935, beliau mendirikan Perusahaan Ternak Missouri, yang kemudian berkembang menjadi sebuah perusahaan keluarga. Setelah Indonesia merdeka sekitar tahun 1947, beliau memutuskan untuk membuka kantor pemasaran di Kota Bandung, tepatnya di Jalan Asia Afrika. Pada tahun 1970 sampai dengan saat ini, kantor tersebut berpindah lokasi ke Jalan Malabar no. 53 Kota Bandung. Pada tahun 1992, didirikan badan hukum dengan nama CV MISSOURI dan terus berkembang sampai saat ini dengan memiliki fasilitas pabrik pakan ternak, pembibitan dan penetasan ayam ras.

\section{Matriks IFE dan EFE}

Berdasarkan analisis lingkungan internal dan eksternal, diperoleh hasil berupa nilai matriks yang menentukan posisi strategi CV Missouri Manajemen IKM 
untuk dijadikan acuan dalam memformulasikan alternatif strategi yang diperoleh. Perumusan strategi pemasaran ini tidak terlepas dari aspek dimensi lingkungan internal dan eksternal.

Berdasarkan hasil penjumlahan skor total pada matriks IFE dan EFE didapatkan nilai masing-masing 2,69 dan 2,70. Skor total yang terdapat pada matriks EFE menggambarkan dan mengindikasikan posisi strategi CV Missouri stabil dalam merespon situasi eksternal yang dihadapi. Skor total IFE mengindikasikan posisi strategi CV Missouri berada pada tingkat rataan untuk mampu merespon iklim internal dan eksternal yang dimiliki.

Nilai skor total kombinasi antara matriks IFE dan EFE digunakan untuk mengetahui posisi strategi CV Missouri (Gambar 1). Berdasarkan kombinasi dari nilai IFE dan EFE didapatkan matriks IE. Nilai matriks IE menunjukkan pada posisi kuadran V (Pertumbuhan/Stabil).

\section{Matriks IE}

Penentuan posisi strategi perusahaan dalam matriks IE didasarkan pada hasil total nilai matriks IFE yang diberi bobot pada sumbu $x$ dan total nilai matriks EFE pada sumbu y (David, 2006). Posisi matriks IE menunjukkan posisi strategi pertumbuhan dan stabilitas. Strategi pertumbuhan ini didesain untuk mencapai kondisi pertumbuhan penjualan, pertumbuhan keuntungan dan pertumbuhan aset. Usaha yang dapat dilakukan adalah penetrasi pasar dan pengembangan usaha, misalnya (a) memberikan jaminan mutu DOC PS dan FS Broiler sesuai SNI yaitu berat DOC untuk ayam ras pedaging $P S$ dan FS minimal 35 gram (b) melakukan kontrak penjualan DOC selama setahun dengan harga pokok produksi. Sistem ini menguntungkan peternak karena dalam setahun harga DOC tidak berfluktuasi (naik turun). Sistem kontrak ini bagi perusahaan akan mendapatkan dana segar yang besar, walaupun keuntungan sedikit tetapi modal selalu dapat berputar, (c) mengembangkan usaha diluar usaha pembibitan ayam ras karena usaha pembibitan sudah mulai jenuh, misalnya membuat Rumah Pemotongan Hewan Unggas (RPHU) yang dilengkapi fasilitas rantai dingin, mengembangkan usaha properti dan perbengkelan serta ekspansi ke usaha pakan ternak (feedmill)

Kegiatan untuk peningkatan pemasaran dan pelayanan merupakan salah satu formulasi strategi yang dapat menjadi andalan utama bagi $\mathrm{CV}$ Missouri, disamping untuk mengembangkan kegiatan usaha juga bertujuan untuk mempertahankan usaha, agar terus berlangsung dan terhindar dari kehilangan penjualan dan kehilangan keuntungan. Hasil identifikasi dari kekuatan, kelemahan, peluang dan ancaman perusahaan digunakan untuk merumuskan alternatif strategi dengan menggunakan matriks SWOT.

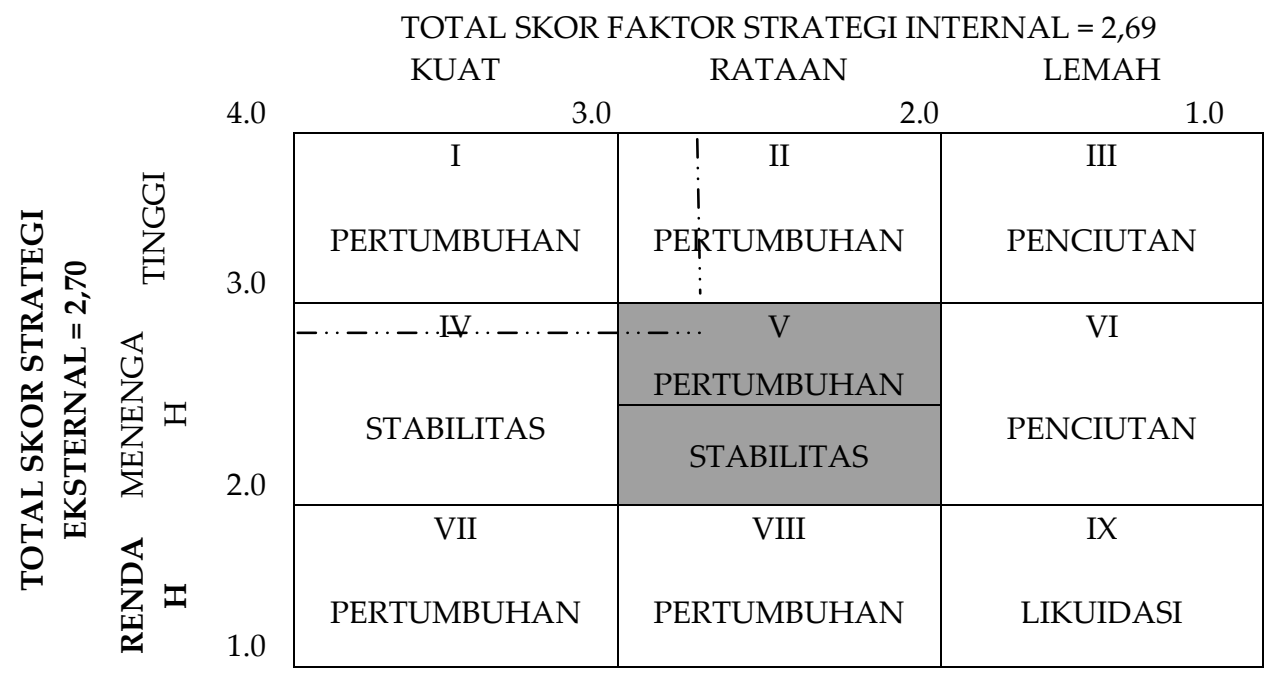

Gambar 1. Analisis Matriks IE 


\section{Perumusan Strategi SWOT}

Fokus dari alternatif strategi pemasaran (Gambar 2) DOC CV Missouri dengan penggunaan kekuatan bagi pemanfaatan peluang adalah:

a. Memperluas jaringan pemasaran dengan menggunakan tenaga kerja sesuai keahliannya. Diperlukan suatu pola pemasaran dan kemampuan manajerial yang dapat meningkatkan perusahaan agar lebih kuat. Pola ini mencakup tenaga pemasaran yang handal dan memiliki kemampuan menguasai pasar sesuai dengan bidang usaha pemasaran DOC. Selain itu juga harus didukung dengan kemampuan manajerial pemilik perusahaan, seperti kemampuan mengarahkan tenaga kerjanya dan kemampuan melihat pangsa pasar yang ada. Pemasaran merupakan proses kegiatan menyalurkan produk dari produsen ke konsumen. Pemasaran merupakan puncak dari kegiatan ekonomi dalam agribisnis peternakan (Mappigau et al., 2011).

b. Menciptakan produk DOC yang lebih baik dengan melihat perkembangan dan keinginan masyarakat luas. Produk memiliki arti penting bagi perusahaan karena tanpa adanya produk, perusahaan tidak akan dapat melakukan apapun dari usahanya (Hayati, 2015). Dalam hal ini, pengembangan produk DOC yang lebih baik untuk meningkatkan pengembangan perusahaan, baik dari pemilik maupun tenaga kerja untuk melihat peluang dengan adanya produk DOC yang lebih baik tersebut, sehingga ada proses timbal balik antara tenaga kerja dan pemilik perusahaan. Hubungan baik yang sudah terbina akan memperlancar proses produksi dan proses pemasaran.

\begin{tabular}{|c|c|c|}
\hline Faktor Eksternal & $\begin{array}{l}\quad \text { Faktor kekuatan (S) } \\
\text { 1. Sistem pemasaran } \\
\text { 2. Produksi DOC optimal } \\
\text { 3. Luas dan besar ruangan produksi } \\
\text { yang disiapkan } \\
\text { 4. Sistem keuangan }\end{array}$ & $\begin{array}{l}\quad \text { Faktor kelemahan }(\mathbf{W}) \\
\text { 1. Sistem manajemen } \\
\text { 2. Sistem informasi } \\
\text { 3. Fasilitas dan peralatan yang } \\
\text { memadai untuk produksi } \\
\text { 4. Kebijakan Pemerintah tentang } \\
\text { produksi DOC }\end{array}$ \\
\hline $\begin{array}{l}\text { Faktor peluang }(\mathrm{O}) \\
\text { 1. Daya tawar pembeli } \\
\text { DOC } \\
\text { 2. Sistem penerapan } \\
\text { teknologi } \\
\text { 3. Kondisi demografi } \\
\text { penyaluran DOC } \\
\text { 4. Kebutuhan DOC di } \\
\text { masyarakat }\end{array}$ & $\begin{array}{l}\quad \text { Strategi SO (agresif) } \\
\text { 1. Memperluas jaringan pemasaran } \\
\text { dengan optimal (O1,O2,O3; } \\
\text { S1,S2,S3) } \\
\text { 2. Menciptakan DOC yang lebih } \\
\text { baik dengan meningkatkan } \\
\text { produktivitas (O1,O2,O3,O4; } \\
\text { S1,S2,S3) } \\
\text { 3. Menambah permodalan agar } \\
\text { dapat bersaing dengan pesaing } \\
\text { (O3,O4; } 1, \mathrm{~S} 2)\end{array}$ & $\begin{array}{l}\text { Strategi WO (diversifikasi) } \\
\text { 1. Meningkatkan volume penjualan } \\
\text { dengan meningkatkan efektifitas } \\
\text { pemasaran }(\mathrm{O} 1, \mathrm{O} 2, \mathrm{O} 3, \mathrm{O} 4 ; \\
\mathrm{W} 1, \mathrm{~W} 2, \mathrm{~W} 3) \\
\text { 2. Memanfaatkan sistem informasi } \\
\text { dalam meningkatkan penjualan } \\
(\mathrm{O} 2, \mathrm{O} 3, \mathrm{O} 4 ; \mathrm{W} 1, \mathrm{~W} 2, \mathrm{~W} 3) \\
\text { 3emanfaatkan kebijakan peme- } \\
\text { rintah sesuai kebutuhan masyara- } \\
\text { kat(O2,O3,O4; W1,W2,W3) }\end{array}$ \\
\hline $\begin{array}{l}\text { Faktor ancaman }(\mathrm{T}) \\
\text { 1. Kondisi ekonomi } \\
\text { masyarakat } \\
\text { 2. Pendatang perusahaan } \\
\text { sejenis } \\
\text { 3. Persaingan antar } \\
\text { perusahaan sejenis } \\
\text { 4. Kondisi politik saat ini }\end{array}$ & \begin{tabular}{ll} 
& \multicolumn{1}{c|}{ Strategi ST (diferensiasi) } \\
1. & Mempertahankan dan menjaga \\
mutu produk yang dihasilkan \\
(T1,T2,T3,T4; S1,S2,S3) \\
2. \\
Meningkatkan pelayanan dan \\
loyalitas konsumen (T1,T2,T3; \\
S1,S3) \\
3. Konsisten mempertahankan \\
produktivitas untuk diterima pasar \\
(T1,T2,T3,T4; S1,S2,S3,S4)
\end{tabular} & \begin{tabular}{l}
\multicolumn{1}{c}{ Strategi WT (defensif) } \\
1. Meningkatkan teknologi produksi \\
dan mutu produk (T1,T2,T3; \\
W1,W2,W3) \\
2. Memperbaiki mutu SDM \\
(T1,T2,T3,T4; W1,W2,W4) \\
3. Meningkatkan kerjasama dengan \\
pihak lain dalam bentuk kemitraan \\
(T1,T2,T3; W1,W2,W3)
\end{tabular} \\
\hline
\end{tabular}

Keterangan : (Oi; Si) atau (Oi; Wi) atau (Ti; Si) atau (Ti; Wi) menunjukkan kombinasi lingkungan eksternal dengan internal dalam menghasilkan pilihan strategi. $\mathrm{i}=1,2, \ldots \ldots . . \mathrm{n}$. 
c. Memperkuat permodalan perusahaan agar dapat bersaing dengan pesaing. Untuk itu diperlukan penambahan modal untuk meningkatkan pangsa pasar. Faktor pasokan modal merupakan peluang perusahaan dalam meningkatkan kapasitas produksinya. Modal yang dikeluarkan dalam bentuk investasi akan memengaruhi skala usaha yang berdampak langsung pada pendapatan (Rahayu, 2013). Strategi yang dapat digunakan adalah dengan mengoptimalkan modal usaha dan meningkatkan kemampuan dalam pengembangan perusahaan (Hidayati, 2017).

Memperhatikan peta strategi tersebut, maka pengembangan ke depannya, perusahaan perlu memperhatikan ketepatan dalam menentukan lokasi usaha (kredibel, transportasi, biaya, peraturan dan lainnya), perekrutan tenaga kerja dan hal relevan lainnya untuk meraih keberhasilan perusahaan.

\section{Perumusan strategi QSPM}

Berdasarkan hasil perhitungan dalam matrik QSP, diperoleh strategi yang paling tepat diimplementasikan adalah mempertahankan dan menjaga mutu produk yang dihasilkan, dengan total nilai daya tarik tertinggi diantara alternatif strategi lainnya, yaitu 6,08. Fokus strategi dengan nilai daya tarik tertinggi adalah:

a. Jaminan mutu DOC sesuai dengan SNI (Standar Nasional Indonesia). Hal ini penting karena untuk menjaga mutu DOC, yaitu berat minimal untuk broiler 35 gram dan untuk layer 33 gram.

b. DOC setting by order. Penjualan DOC PS dan FS dilakukan berdasarkan pemesanan terlebih dahulu. Strategi ini dilakukan untuk menghindari over suplai (menumpuk) di hatchery akibat DOC tidak laku terjual, yaitu dengan cara pemesanan DOC broiler minimal 1 bulan sebelumnya, DOC layer minimal 3 bulan sebelumnya dan DOC PS (broiler dan layer) minimal 6 bulan sebelumnya. Hal ini sangat penting untuk menjaga mutu produk yang dihasilkan, baik untuk peternak maupun perusahaan.

c. Melakukan afkir induk lebih cepat. Apabila harga DOC FS sudah mulai turun, sebaiknya perusahaan langsung melakukan afkir dini induk. Hal ini dilakukan agar dapat mengurangi biaya produksi, seperti biaya pakan, listrik dan tenaga kerja harian. Selain itu juga untuk mendapatkan harga penjualan induk afkir yang tinggi (Rp20.000-22.000/kg).

d. Mengadakan pelatihan dan pengetahuan karyawan tentang pentingnya mutu produk. Pelatihan ditujukan untuk meningkatkan keterampilan teknis dan kapabilitas manajerial perusahaan (Hanum et al., 2011).

Total nilai daya tarik urutan kedua (2) adalah meningkatkan pelayanan dan loyalitas konsumen yaitu 5,95. Disamping standar layanan bagi pelanggan/konsumen, perhatian terhadap konsumen merupakan hal yang harus diperhatikan dan dilaksanakan oleh perusahaan. Adanya pelayanan yang memuaskan maka konsumen akan merasa dihargai. Pelayanan yang memuaskan, mencakup sikap (kerapian, kesopanan dan keramahan) karyawan dan fasilitas yang memadai. Kemampuan karyawan dalam memberikan pelayanan yang dijanjikan dengan segera, akurat dan memuaskan seperti ketepatan waktu, dan kejujuran akan memberikan kepuasan terhadap konsumen (Yansah et al., 2013). Fokus strategi dengan nilai daya tarik kedua adalah:

a. Menjaga loyalitas konsumen dengan totalitas tinggi. Karena kebanyakan konsumen adalah generasi lama yang mewariskan bisnis ayamnya ke generasi berikutnya. Untuk itu perlu peran perusahaan dalam membina dan memberikan pendampingan kepada para peternak. Misalnya saat harga pasaran DOC tinggi, perusahaan dapat memberikan harga jual dengan harga lama kepada konsumen yang loyal, sehingga dapat saling menguntungkan. Komunikasi dengan konsumen dapat dilakukan dengan melalui telepon, silaturahmi ke farm atau acara gathering.

b. Melakukan kontrak penjualan DOC. Perusahaan memberikan kontrak penjualan DOC selama setahun dengan harga pokok produksi (HPP). Sistem ini dapat menguntungkan peternak atau konsumen loyal karena dalam setahun harga DOC tidak berfluktuasi (naik turun). Selain menguntungkan peternak, perusahaan juga mendapatkan dana segar yang stabil, walaupun sedikit keuntungan tetapi modal selalu dapat berputar.

c. Melayani penjualan DOC kepada konsumen secara langsung. Bagi peternak yang membeli dengan jumlah kecil (minimal 100 ekor atau 1 box) dapat membeli langsung ke toko $\mathrm{CV}$ Missouri.

Total nilai daya tarik yang ketiga adalah menambah permodalan agar dapat bersaing 
dengan pesaing dengan nilai 5,94. Menambah permodalan tidak harus melalui perbankan. Modal usaha CV Missouri sangat kuat, karena modal yang digunakan untuk operasional perusahaan tidak menggunakan perbankan, tetapi berasal $100 \%$ dari dana yang dimiliki oleh perusahaan. CV Missouri yang merupakan perusahaan keluarga dan sudah ada sejak tahun 1935 sehingga memiliki pemodalan yang kuat. Dalam melaksanakan kegiatan operasional perusahaan, dana yang digunakan baru sebesar $40 \%$ dari total dana yang dimiliki. Sisanya $60 \%$ masih tersimpan sebagai dana cadangan dalam bentuk simpanan bank, kepemilikan tanah dan bangunan. Oleh karena itu dengan dana yang masih tersedia dan pengalaman yang sudah lama dalam bidang perunggasan, perlu dilakukan pemeliharaan ayam dengan system battery, pengembangan usaha dari kandang open house menjadi close house dan perluasan perusahaan atau ekspansi ke luar Pulau Jawa, sehingga memberikan prospek yang baik bagi perusahaan. Urutan prioritas strategi dari hasil matriks QSP dapat dilihat pada Tabel 2.

\section{KESIMPULAN}

Berdasarkan hasil penelitian, maka disimpulkan faktor-faktor yang dihadapi oleh CV Missouri dalam pemasaran DOC ayam ras pedaging adalah (1) faktor internal terdiri dari produksi DOC, sistem keuangan, ruangan produksi, sistem pemasaran, fasilitas produksi, sistem manajemen, sistem informasi dan kebijakan pemerintah tentang ayam ras; dan (2) faktor eksternal terdiri dari penerapan teknologi, daya tawar pembeli, kebutuhan DOC di masyarakat, kondisi demografi penyaluran $D O C$, kondisi ekonomi masyarakat, persaingan antar perusahaan sejenis, pendatang perusahaan sejenis dan kondisi politik saat ini. Posisi strategis perusahaan CV Missouri berdasarkan analisis Matrik IE berada pada kuadran V, yaitu strategi pertumbuhan dan stabilitas (growth and stability), hal ini menunjukkan bahwa perusahaan ini memiliki strategi pertumbuhan dan stabilitas yang baik. Selanjutnya, strategi pemasaran DOC CV Missouri berdasarkan analisis SWOT adalah (a) memperluas jaringan pemasaran dengan optimal. (b) menciptakan DOC yang lebih baik dengan meningkatkan produktivitas, (c) menambah permodalan perusahaan agar dapat bersaing dengan pesaing, karena itu dibutuhkan tambahan modal untuk memperlebar peluang pasar. Alternatif strategi yang bisa diterapkan oleh CV Missouri berdasarkan hasil analisis Matrik QSP, yaitu (1) mempertahankan dan menjaga mutu produk yang dihasilkan, dan (2) meningkatkan pelayanan dan loyalitas konsumen.

\section{DAFTAR PUSTAKA}

David, F.R. 2011. Manajemen Strategi (Terjemahan). PT Prenhallindo. Jakarta (ID).

Ekapriyatna, I.D.G.B., I.M. Nuridja, A. Zukhri. 2016. Analisis Strategi Pengembangan Usaha Peternakan Ayam Pedaging (Broiler) Ananta Guna di Desa Sidan Kecamatan Gianyar Kabupaten Gianyar. Jurnal Program Studi Pendidikan Ekonomi (JPPE). 7 (2): 1-13.

Tabel 2. Urutan prioritas strategi dari matriks QSP

\begin{tabular}{rlcc}
\hline No. & \multicolumn{1}{c}{ Alternatif Strategi } & $\begin{array}{c}\text { Total nilai } \\
\text { daya tarik }\end{array}$ & $\begin{array}{c}\text { Urutan } \\
\text { Prioritas }\end{array}$ \\
\hline 1. & Mempertahankan dan menjaga mutu produk yang dihasilkan & 6,08 & 1 \\
2. & Meningkatkan pelayanan dan loyalitas konsumen & 5,95 & 2 \\
3. & Menambah permodalan agar dapat bersaing dengan pesaing & 5,94 & 3 \\
4. & Meningkatkan teknologi produksi dan mutu produk. & 5,87 & 4 \\
5. & Konsisten mempertahankan produktivitas untuk diterima pasar & 5,80 & 5 \\
6. & Memperluas jaringan pemasaran yang optimal & 5,76 & 6 \\
7. & Meningkatkan volume penjualan dengan meningkatkan efektifitas & 5,71 & 7 \\
& pemasaran & & 8,58 \\
8. & Menciptakan DOC yang lebih baik dengan meningkatkan & & 8 \\
9. & produktifitas & 5,46 & 9 \\
10. & Memanfaatkan sistem informasi dalam meningkatkan penjualan & 5,04 & 10 \\
11. & Memanfaatkan kebijakan pemerintah sesuai kebutuhan masyarakat & 4,74 & 11 \\
12. & Meningkatkan kerjasama dengan pihak lain dalam bentuk kemitraan & 4,08 & 12 \\
\hline
\end{tabular}


Hanum, L., Bunasor, S., Maulana, A. 2011. Strategi Pengembangan Kemitraan Ternak Ayam Broiler PT. XYZ. Jurnal Manajemen dan Agribisnis. 8 (2): 75-83.

Hayati, Y.H., S. Gracia. 2015. Pengaruh Kualitas Produk Terhadap Kepuasan Konsumen di Restoran Bebek dan Ayam Goreng Pak Ndut Solo. Jurnal Ilmiah Manajemen Fakultas Ekonomi (JIMFE). 1 (1): 49-56.

Hidayati, P.I. 2017. Analisis Strategi Pengembangan Agribisnis Peternakan Ayam Ras di Kabupaten Probolinggo Jawa Timur. Jurnal Optima. 1 (1): 23-31.

Jaelani, A., M. Suslinawati. 2013. Analisis Kelayakan Usaha Peternakan Ayam Broiler di Kecamatan Tapin Utara Kabupaten Tapin. Jurnal Ilmu Ternak. 13 (2): 42-48.

Mappigau, P., A.S.R. Esso 2011. Analisis Strategi Pemasaran Telur Pada Peternakan Ayam Ras Skala Besar di Kabupaten Sidrap. Jurnal Agribisnis. 10 (3): 14-31.

Mubyarto. 1989. Pengantar Ekonomi Pertanian Edisi III. Lembaga Penelitian, Pendidikan dan Penerangan Ekonomi dan Sosial (LP3ES). Jakarta (ID).

Priyadi, U., S. Indah, S.D. Awan. 2004. Analisis Distribusi Ayam Broiler di Propinsi Daerah Istimewa Yogyakarta. Jurnal Ekonomi Pembangunan. 9 (2): 193-205.
Rahayu, E.T. 2013. Analisis Pendapatan Ternak Sapi Perah di Kecamatan Cepogo Kabupaten Boyolali. Jurnal Sains Peternakan. 11 (2): 99-105.

Rangkuti. F. 2008. Analisis SWOT Teknik Membedah Kasus Bisnis. Gramedia Pustaka Utama, Jakarta. (ID).

Soekartawi. 1995. Analisis Usahatani. Universitas Indonesia. Jakarta (ID).

Siregar, A.P., Sabrani, N., Pramu, S. 2005. Teknik Beternak Ayam Pedaging di Indonesia. Margie Group. Jakarta (ID).

Tulle, D.R., A.J. Johanis, I.K. Jaya, A.Y.F. Tri. 2016. Karakteristik Pemasaran Ayam Broiler pada Beberapa Skala Pemeliharaan di Kota Kupang. Jurnal Partner. 2 (1): 95-102.

Yansah, R.A., B. Hartono. dan M.B. Hariyono. 2013. Analisis Kualitas Pelayanan (Service Quality) terhadap Kepuasan Konsumen pada Rumah Makan Sop Ayam Pak Min Klaten di Malang. Jurnal Ilmu-Ilmu Peternakan. 23 (1): 30-34.

Yemima. 2014. Analisis Usaha Peternakan Ayam Broiler pada Peternakan Rakyat di Desa Karya Bakti, Kecamatan Rungan, Kabupaten Gunung Mas, Provinsi Kalimantan Tengah. Jurnal Ilmu Hewani Tropika. 3 (1): 27-32. 